\title{
"I remember things, but I can't picture them." What can a case of aphantasia tell us about imagery and memory?
}

\author{
„Pamiętam różne rzeczy z przeszłości, ale nie mogę ich zobaczyć". Co przypadek afantazji \\ mówi nam o funkcjonowaniu wyobraźni i pamięci?
}

\author{
Department of Psychology, Pedagogical University of Krakow, Krakow, Poland \\ Correspondence: Joanna Ganczarek, Department of Psychology, Pedagogical University of Krakow, Podchorążych 2, 30-084 Krakow, Poland, tel.: +48 12 662 62 34, e-mail: joanna.ganczarek@up.krakow.pl
}

Abstract Aphantasia is a relatively new term referring to the experience of lack of visual imagery. Here, we present a literature review on aphantasia in the context of memory as well as a case report of congenital aphantasia in a 24-year old female, A.B., who became aware of her particular condition only recently. The aim of this article is to draw attention to the concept of aphantasia and describe the patient's experiences as well as her performance in mental imagery, memory, and intelligence tests. We believe that our paper may be useful for both research in psychology and clinical practice. Analysis of aphantasia may allow to assess the importance of mental imagery in other cognitive processes, like working memory or autobiographical memory. Moreover, the phenomenon of aphantasia emphasises the need to consider individual differences in mental imagery and inspires new research. Last but not least, we present a series of psychotherapeutic implications of aphantasia, such as deficits in autobiographical memory or difficulties with imagery-based techniques.

Keywords: aphantasia, imagery, memory, individual differences, psychotherapy

Streszczenie Afantazja jest stosunkowo nowym pojęciem opisującym brak wyobraźni wzrokowej. W niniejszym artykule prezentujemy przegląd literatury na temat tego zjawiska w kontekście funkcjonowania pamięci. Przedstawiamy również studium przypadku wrodzonej afantazji u 24-letniej kobiety, A.B. Artykuł ma na celu przybliżenie pojęcia afantazji poprzez opisanie jej fenomenologicznego doświadczenia oraz wyników w testach mierzących wyobraźnię wzrokową, pamięć oraz inteligencję. Prezentacja zjawiska afantazji może być użyteczna zarówno dla badań prowadzonych w obrębie psychologii poznawczej, jak i w obszarze praktyki klinicznej. Dla psychologii poznawczej szczególne znaczenie może mieć fakt, że afantazja umożliwia ocenę roli wyobraźni w innych procesach poznawczych, takich jak pamięć robocza czy autobiograficzna. Dodatkowo zjawisko afantazji uświadamia konieczność uwzględniania różnic indywidualnych w zakresie wyobraźni oraz inspiruje nowe kierunki badań. Ponadto, w związku z tym, że afantazja wiąże się z ograniczeniami w zakresie funkcjonowania pamięci autobiograficznej oraz trudnościami w korzystaniu z technik opartych na wizualizacjach, wskazujemy na praktyczne implikacje dla psychoterapii.

Słowa kluczowe: afantazja, wyobraźnia, pamięć, różnice indywidualne, psychoterapia 


\section{THE CONCEPT OF APHANTASIA}

"C phantasia" is a term proposed by Zeman et al. (2015) to describe a condition where one lacks or has a reduced ability to visualise absent objects. It refers mainly to voluntary imagery as some people with aphantasia can still experience involuntary visualisations (e.g. in dreams).

One of the first ever described cases of aphantasia was the M.X. patient (Zeman et al., 2010). He reported a sudden loss of visual imagery after coronary angioplasty. Interestingly, his dreams also lost their visual content. He described his experiences this way: "I can remember visual details but I can't see them... I can't explain that... From time to time I do miss being able to see" (Zeman et al., 2010, p. 147). It suggests that M.X. relied on memory rather than imagery when recognising familiar faces or describing familiar routes or pictures. This hypothesis can be supported by neuroimaging, which demonstrated that M.X. had a different pattern of brain activations from control participants during imagery tasks (decreased activation in posterior regions related to visual imagery, but increased activation in anterior regions responsible for, among other things, executive functions) (Zeman et al., 2010). One year after the surgery, M.X. claimed that he would occasionally experience a fleeting visual image of a place mentioned in a conversation and his dreams regained their visual qualities, but he could still not visualise voluntarily.

While M.X. is a case of acquired aphantasia following a surgical procedure, the case of S.E. demonstrates that aphantasia could also develop independently of an organic cause and may be related to a psychological stressor (dos Santos et al., 2018). S.E. stated that his experience of aphantasia began early in his life around the time his father left him. Similarly to M.X., he lost the ability to access visual features of objects in his imagery. He also reported having intact abilities to experience spatial and emotional properties of objects or events. He said: "If I close my eyes and think about my wife or kids, I sense physical space, facial features that are unique to my wife and kids are not seen but the feeling of these features is there. I can sense my emotional attachment to them deeply. I can hear their voices, I can sense their touch, but I cannot see them. (...) When dreaming about being chased by a monster I can feel I am moving through space and I experience intense fear, but the monster has no form, it is a terrifying felt presence that is coming after me" (dos Santos et al., 2018, p. 75).

Both of the cases above refer to people with acquired aphantasia because their symptoms started at some point of life. However, there are also reports of cases of congenital aphantasia, where people claim that they were never able to form images in their minds. One case of congenital aphantasia was reported by Watkins (2018). He described his own aphantasia as a kind of "invisible imagery" (Watkins, 2018, p. 44) because when his eyes were closed everything appeared black to him. At the same time, he gives an account of normal perceptual experiences when facing external stimuli.
The way aphantasia is experienced differs between individuals, but some common aspects can be identified. Aphantasics refer to memory or conceptual knowledge rather than to imagery when retrieving information (Ross, 2016; dos Santos et al., 2018; Watkins, 2018; Zeman et al., 2010). The impairment of imagery may involve different modalities (Watkins, 2018; Ross, 2016) or specifically impede visual modality only (dos Santos et al., 2018). Finally, aphantasic individuals report experiencing sensations of imagined physical space and ability to experience emotions in response to people or situations that are dear to them despite being unable to visualise them (dos Santos et al., 2018; Watkins, 2018).

As can be seen from this brief introduction, aphantasia, either congenital or acquired, taps into some important issues for cognitive psychology, such as perception, imagery, and memory. As a consequence, it has already inspired research into various cognitive mechanisms underlying the "blind imagination."

\section{APHANTASIA AND MEMORY}

The relationship between aphantasia and memory is mentioned in Zeman's account of the M.X. patient. In fact, it seems that aphantasia may provide an interesting opportunity to study the relationship between memory and imagery. Usually, in order to separate memory from imagery, researchers have to employ complex experimental procedures and consider the vividness of mental imagery as a correlate of performance in memory tasks (e.g. Baddeley and Andrade, 2000; Gur and Hilgard, 1975; Keogh and Pearson, 2011, 2014). Instead, in aphantasic individuals we can observe how memory works in the absence of mental imagery. To the best of our knowledge, among the different types of memory, aphantasia has been studied in the context of visual working memory and autobiographical memory.

When it comes to visual working memory, mental imagery seems to be important both from a theoretical (e.g. Baddeley, 1992) and experimental perspective (e.g. Baddeley and Andrade, 2000; Bruyer and Scailquin, 1998; Keogh and Pearson, 2011, 2014). However, the results of studies investigating the relationship between mental imagery and visual working memory are somewhat inconsistent in terms of both the direction of this relationship and even its existence (Baddeley and Andrade, 2000; Gur and Hilgard, 1975; Keogh and Pearson, 2011; Reisberg and Leak, 1987; Heuer et al., 1986).

Jacobs et al. (2018) has recently described a relationship between aphantasia and working memory capacity. Their patient (A.I.) and a control group of 11 good imagers executed a series of tasks designed to measure visual working memory. In general, A.I. performed as well as controls in working memory tests. However, a slight impairment was noted when the visual working memory task required a high level of precision. Therefore, it seems that mental imagery is not necessary for passing working memory tests. Instead, it can 
be viewed as a mnemonic strategy boosting performance in difficult tasks involving visual working memory, and it may be unavailable to some individuals. In the patient's introspective reports, mental imagery was described as a form of knowledge rather than perception with the mind's eye. This "knowledge" might work well for spatial or verbal tasks, but it may not be sufficient for tasks that require visual processing. In fact, Keogh and Pearson (2018) found that aphantasic individuals used spatial imagery even more often than non-aphantasic subjects despite their impaired visual imagery. Therefore, it is possible that aphantasia does not involve a complete lack of imagery, but only an impairment of one particular type of imagery i.e., visual imagery. This is in line with theories emphasising that mental imagery is not a uniform process, but a compound of distinct subprocesses (e.g. Kosslyn et al., 2001; Paivio, 1991). Drawing on these complex theories of imagery, Blazhenkova and Kozhevnikov's (2009) developed a model of cognitive styles that comprise spatial and object imagery as well as verbal cognitive style. Object imagery would refer to precise appearances of objects, such as a clear representation of their form, colour, size, shape, etc. (Blajenkova et al., 2006). Spatial imagery, on the other hand, refers to a more abstract representation of the spatial relations between objects including their relative position or movement in space. The difference between these two types of imagery has been seen in multiple studies (e.g. Kozhevnikov et al., 2002, 2005), suggesting that object imagery relies on the construction of vivid high-resolution mental images, whereas spatial imagery entails very schematic representations of spatial transformations. Finally, the verbal cognitive style was also added to the model and is associated with high verbal expression and fluency and a preference for sequential, verbal processing when learning or solving tasks. Importantly, people can have high or low scores in all three dimensions as well as a more specialised profile i.e., low object but high spatial and verbal skills (Blazhenkova and Kozhevnikov, 2009). The model of cognitive styles has been successfully tested and various correlates of cognitive styles have been identified (Kozhevnikov et al., 2013; Vannucci and Mazzoni, 2009; Vannucci et al., 2016). From this perspective, aphantasia can be seen as either an impairment of object imagery with intact spatial imagery, or even a cognitive style with a pronounced preference for spatial visualisation and/or verbal processing. This would explain why aphantasic individuals perform as well as the general population in visual working memory tasks with a medium level of difficulty (Jacobs et al., 2018). In this case, rather than using object imagery, they may rely on other types of imagery, such as spatial imagery or verbal strategy. Only when tasks require high precision of visual information, aphantasic individuals would not perform as well because the object imagery may offer an advantage in such cases (Jacobs et al., 2018).

Moreover, it may also be important to consider the phenomenon of aphantasia within the context of yet another type of memory, i.e. autobiographical memory, and its relevance for clinical practice. Given that psychotherapy relies heavily on autobiographical memory, aphantasia might present a challenge. It seems that aphantasia might be related to severely deficient autobiographical memory (SDAM), which refers to a lifelong inability to vividly recollect or reexperience personal past events from a first-person perspective. The link between SDAM and aphantasia was described by Watkins (2018), who claims that even though visual imagery is not absolutely necessary for self-awareness, its impairment can lead to difficulties with autobiographical memory and the sense of self. This conclusion is also supported by research showing that the lack of ability to create mental images is connected with limited access to episodic and emotional information about past personal experiences (Palombo et al., 2015) and even with problems with identity (Simeon et al., 2000; de Vito and Bartolomeo, 2016). Research on the relationships between visual imagery and autobiographical memory indicates that "blind imagination" causes difficulties in: (1) richness of visual and auditory attributes of a memory and (2) the possibility to re-live personal events from the past (Greenberg and Knowlton, 2014; Watkins, 2018). People with aphantasia have knowledge of various episodes of their biography, but they find it difficult to mentally travel in time to imagine themselves in any of them. Also, the emotional aspects of past events may be less available to them. Some studies suggest that the limited access to the emotional information about one's past may be associated with depression, anxiety disorders, and experiences of depersonalisation or derealisation (Simeon et al., 2000; de Vito and Bartolomeo, 2016). Summing up, the so-called blind imagination might be related to difficulties in retrieval of the emotional and sensory attributes of one's autobiographical memories with intact knowledge about the facts. Moreover, it might affect the sense of re-living when recalling autobiographical memories and may be associated with personal or even clinical problems, such as depression or anxiety.

In order to further illustrate the phenomenon of aphantasia and its connections with memory, we complement this review with a case study. We believe that this will allow a closer look at how aphantasia is experienced and how it manifests itself in interviews and imagery and memory tests.

\section{CASE STUDY}

The case study we present is an idiographic analysis of the phenomenon of aphantasia aimed to enrich the literature review with descriptive, exploratory, and critical information. In particular, we analysed aphantasia with respect to subject's experience of the disorder and how it affects her functioning in terms of imagery and memory. A.B. is a 24 -yearold woman, a senior year psychology student who suffers from congenital aphantasia. She has a younger brother and an older sister. Her father is an electrician and her mother is a saleswoman by profession. No one from the family 
reported similar problems with imagery. At 3 years of age, A.B. was diagnosed with bilateral hearing loss (over 50\%). She has been using hearing aids since childhood. She has no history of head injuries, serious diseases or surgeries. Her first contact with the definition of aphantasia was while reading popular science articles on the Internet; however, she was unsure if it was relevant to her. It was only later, during classes, did she realise that, unlike other students, she was not able to form mental images. Eager to learn more about what was going on in her mind, she looked for information about aphantasia on the Internet, and then, eventually, contacted one of the authors.

\section{METHODS}

Qualitative and quantitative research methods were used to study the phenomenon of aphantasia. The authors obtained a written statement of informed consent from the participant.

\section{Qualitative methods}

Due to the atypical phenomenon of aphantasia, it was considered valuable to obtain information on the personal experience of aphantasia and the qualitative characteristics of autobiographical memories. For this purpose, a semi-structured general interview about aphantasia and a structured specific interview on autobiographical memory (inspired by Kopelman et al., 1989) were used.

\section{Semi-structured general interview about aphantasia}

The purpose of the semi-structured general interview was to gather information on how aphantasia is experienced at a phenomenological level. The interview covered three aspects: (1) personal significance of aphantasia, (2) manifestations of aphantasia, (3) and the impact of aphantasia on daily functioning. We adopted an inductive approach and a phenomenological analysis.

\section{Structured specific interview \\ on autobiographical memory}

The structured specific interview aimed at activating personalised semantic and episodic memory and recalling autobiographical memories of three life periods: childhood, early adulthood, and recent life events. We were interested in the specificity of autobiographical memory in aphantasia. The qualitative analysis and interpretation of the acquired material was analysed by 2 competent judges using categories designed for the purposes of the study to assess autobiographical memories. The categories were developed based on the concept of cognitive styles (e.g. Blazhenkova and Kozhevnikov, 2009; Kozhevnikov et al., 2013) and research on the relationships of aphantasia with autobiographical memory (e.g. Greenberg and Knowlton, 2014; Watkins, 2018). They included the following dimensions:
(1) presence of clear visual imagery regarding e.g. objects, faces; (2) involuntary nature of images; (3) recalling visual details in descriptions (shape, colour, size); (4) presence of other sensory modalities (hearing, smell, touch); (5) preferred narrative style (description focusing on visual details, using adjectives versus building narratives based on cause and effect relationships, using verbs); (6) emotional commitment and meaning of memories (references to sensations, feelings).

\section{Quantitative measures}

The participant's imagery was assessed using two standard questionnaires aimed at evaluating the vividness of visual imagery (Vividness of Visual Imagery Questionnaire, VVIQ) (Marks, 1973) and the spontaneous use of visual imagery (Spontaneous Use of Imagery Scale, SUIS) (Reisberg et al., 2003). They are self-report questionnaires where participants assign vividness to their own mental imagery. It is well documented that people with aphantasia score low in VVIQ (Zeman et al., 2010) and SUIS (Keogh and Pearson, 2018; Walker, 2010; Zeman et al., 2010) which indicates poor visual imagery. In general, VVIQ score of 16 is considered a cut-off point for aphantasia (Jacobs et al., 2018; Keogh and Pearson, 2018; Zeman et al., 2010). Moreover, the participant filled one questionnaire designed to assess differences in imagery, the Object-Spatial Imagery and Verbal Questionnaire (OSIVQ) (Blazhenkova and Kozhevnikov, 2009). The OSIVQ questionnaire contains three subscales measuring preferences for three cognitive styles. Furthermore, mental rotation tests (MRT) (Vandenberg and Kuse, 1978) and Corsi Block-Tapping Task (Kessels et al., 2000) were used to study the spatial imagery and visuospatial working memory, respectively. The MRT score was calculated as the number of correctly solved items, whereas the Corsi Block-Tapping Task scores equalled the last number of blocks that were repeated correctly. Finally, the Wechsler Adult Intelligence Scale - Revised (WAIS-R) in the Polish adaptation (Brzeziński et al., 2007) was applied to measure cognitive abilities and intelligence. The results of the subtests were grouped to provide a verbal IQ score, performance IQ score, and full-scale IQ score.

\section{RESULTS}

\section{Qualitative analyses}

Qualitative analysis of the interviews allowed a description of A.B.'s personal experience of aphantasia and isolation of specific categories that build it.

For a long time A.B. did not realise that her cognitive functioning was different from that in most people. The awareness of aphantasia was growing gradually and eventually became evident: "In cognitive psychology classes (...), when asked to imagine a horse (...) I realised that I actually did not have this picture at all," motivating A.B. to seek further 
information. A.B. treats aphantasia and the associated lack of ability to create mental images as a natural state for her, but she is also aware of the resulting limitations compared to other people. A.B. indicates that she cannot use the benefits of imagination when reading books, studying or relaxing with a "nice image" in her mind. None of this, however, prevented her from achieving good high school grades. She reckons that her memory is less efficient and she reports feeling that some life experiences are unavailable to her: "I feel like I'm losing a little (...) as if I had a slightly poorer life compared to other people." At the same time, however, she believes that the lack of imagination was naturally compensated for by other mental abilities.

The analysis of the interview in terms of the cognitive dimensions of aphantasia indicated that A.B.'s aphantasia is complete. The lack of visualisation of images applies to voluntary and involuntary imagination (images also do not appear in her dreams, she does not fantasise or experience the flow of involuntary images). A.B. can only recall blurred contours of objects or passing colours. When asked to recall the face of a loved one or a friend, she refers more to the knowledge she has rather than to memories accompanied by visualisations - " (...) if I try to remember my mother's face, every time I have a problem to even tell the colour of her hair. I remember that she used to have black hair, then it quickly turned grey (...) I can't see, but I also don't remember if it's completely grey (...) there is a kind of problem here (...) every time I see her, I just try to remember it by force but it doesn't work for me either." The lack of visualisation means that A.B. has trouble remembering the visual details of the way people look. This also applies to autobiographical memories and their differentiation due to personal significance: "(...) it seems to me that I often forget many things and... or remember some insignificant things."
A qualitative analysis of A.B.'s autobiographical memories indicates that the descriptions of the events from her biography contain little visual characteristics (colour, shape, size) or descriptions of other sensual modalities, such as hearing, smell or touch. Her storytelling is an example of a narrative focused on reporting the actions of the characters, a description of cause-effect relationships and their time sequence: "And we were coming back and went from school and left ahead but we went to the side of the school, because there was another way out, smaller. And this gate was unexpectedly closed, because it was later. This gate was closed and instead of returning to the main exit, we decided to go through this gate (...) And he knew that it was better and safer in another place. And he was right, because he went through unscathed, and I ripped my pants at the height of the calf, fortunately the leg was intact (...)." Sentences are built using mainly verbs and nouns, whereas words related to image characteristics, e.g. adjectives, appear sporadically. Descriptions contain few references to personal experiences, emotions, or sensations, making it difficult to determine the narrative tone (pessimistic vs. optimistic) of the statement. The emotional tone of memories can be characterised as neutral. In the descriptions of autobiographical events, although they take the form of a firstperson narrative, the narrator is emotionally distant from the memories and their content. Therefore, it is more difficult to assess their personal significance for the narrator.

\section{Quantitative analyses}

Tab. 1 presents all scores obtained in questionnaires and tests by A.B. As can be noted, A.B.'s scores were low in two imagery questionnaires, VVIQ and SUIS, thus confirming aphantasia. Moreover, she scored very low in object

\begin{tabular}{|c|c|c|c|}
\hline Test & A.B. & Aphantasics & Controls \\
\hline VVIQ & 16 & \begin{tabular}{|l|}
$16^{(1)}$ \\
$19^{(2)}$ \\
$16^{(3)}$ \\
\end{tabular} & $\begin{array}{l}59^{(1)} \\
61.09^{(3)}\end{array}$ \\
\hline SUIS & 18 & \begin{tabular}{|l|}
$21^{(1)}$ \\
$14^{(4)}$ \\
$17.20^{(2)}$
\end{tabular} & $\begin{array}{l}37^{(1)} \\
41^{(4)}\end{array}$ \\
\hline OSIVQ & $\begin{array}{l}22 \text { - object imagery } \\
51 \text { - spatial imagery } \\
51 \text { - verbal imagery }\end{array}$ & $\begin{array}{l}21.53^{(2)}-\text { object imagery, } \\
41.80^{(2)} \text { - spatial imagery }\end{array}$ & $36.53^{(2)}-$ spatial imagery \\
\hline MRT & 15 & & $6.5^{(5)}$ \\
\hline Corsi Block-Tapping Task & $\begin{array}{l}7 \text { - forward span } \\
6 \text { - backward span }\end{array}$ & & $\begin{array}{l}\text { 5-6 items in both forward } \\
\text { and backward span }\end{array}$ \\
\hline \multicolumn{4}{|l|}{ WAIS-R } \\
\hline VIQ & 138 & $\begin{array}{l}134^{(1)} \\
113^{(4)} \\
\end{array}$ & \begin{tabular}{|l|}
$132^{(1)}$ \\
$108.25^{(4)}$ \\
\end{tabular} \\
\hline PIQ & 114 & $\begin{array}{l}130^{(1)} \\
114^{(4)} \\
\end{array}$ & \begin{tabular}{|l|}
$139^{(1)}$ \\
$109.35^{(4)}$ \\
\end{tabular} \\
\hline FSIQ & 128 & $\begin{array}{l}136^{(1)} \\
115^{(4)} \\
\end{array}$ & \begin{tabular}{|l}
$139^{(1)}$ \\
$109.90^{(4)}$ \\
\end{tabular} \\
\hline
\end{tabular}


imagery, but had a higher score in spatial and verbal subscales of OSIVQ. This suggests that A.B. experiences no vivid images and has a preference for spatial and verbal reasoning. Her good performance in spatial tasks is further supported by a higher than usual score in the mental rotation test. Also, despite a clear lack of visual imagery, she performed normally in both the forward and backward span of the Corsi Block-Tapping Task, suggesting good capacity and performance of her working memory, including visuospatial working memory. Moreover, the WAIS-R results indicate that A.B.'s general intellectual ability (full scale IQ, FSIQ) is high. The differences between VIQ and PIQ (verbal IQ and performance IQ) are statistically significant, suggesting that A.B. performed better in verbal rather than performance scales that are based on spatial and visual processing.

\section{THEORETICAL CONCLUSIONS AND PRACTICAL IMPLICATIONS}

Our brief review of research on aphantasia and memory suggests that mental imagery might be a form of a mnemonic strategy to boost one's performance in working memory tasks. Good imagers would use this pictorial strategy to help them solve tasks, whereas poor imagers would rely on a non-image based, possibly verbal or propositional strategy (Keogh and Pearson, 2011). Therefore, aphantasia seems to be a condition where working memory is operating well, but visual imagery is unavailable. Furthermore, if we consider mental imagery as a compound of different processes (e.g. visual, spatial), then aphantasia would not mean a loss of imagery, but only its partial impairment or even a cognitive style that operates on spatial and verbal rather than object-related information. As a consequence, the phenomenon of aphantasia brings to attention complex theories on mental imagery with a particular focus on individual differences.

These conclusions are supported by the case study. As our qualitative and quantitative analyses showed, A.B.'s overall performance in different tests was very good; therefore, aphantasia does not seem to affect general cognitive processing. Yet A.B. presents with some particularities that might be of interest for theoretical and practical reasons. First of all, she reported a complete lack of visual imagery, both voluntary and involuntary, which is confirmed by imagery questionnaires. Despite this inability to visualise, she had detailed knowledge of facts from her past. Secondly, her narrative style is focused on causal relationships between events with very little references to their emotional and sensorial aspects. Thirdly, A.B. scored high in overall intelligence with the highest score in the verbal subscale, and performed well in tests requiring spatial abilities. Finally, she reported a marked preference for using spatial and verbal rather than object-related information when solving problems.

Taken together, these results suggest that aphantasia may allow one to draw a line between knowledge about facts from one's past (autobiographical conceptual knowledge) and sensory-based episodic memory. It seems that aphantasia does not impair conceptual knowledge, but may limit access to sensory appearances and the emotional aspects of episodic memories. As a consequence, aphantasic individuals may have difficulties when retrieving particular sensory or emotional characteristics of past events. We can speculate that, however, this impaired access may be beneficial for distancing oneself from memories of traumatic experiences. On the other hand, it may present a disadvantage when assessing personal significance of memories or be associated with difficulties in the sense of self.

Moreover, A.B. displayed good performance in spatial tests that rely on visuo-spatial working memory, but reported no vivid visual imagery. This result, together with her scores in the OSIVQ questionnaire, suggest that she may use spatial imagery that is based on schematic spatial representations allowing spatial transformations, but lacking the vividness of object imagery. Therefore, as mentioned earlier, aphantasia might reflect a condition where the link between visual object imagery and working memory is missing and a person uses other strategies, namely spatial imagery, to process elements in working memory. This missing link between visual object imagery and working memory is of great interest for cognitive psychology as it permits the separation of working memory from visual imagery. Moreover, the phenomenon of aphantasia touches on some important issues in cognitive science, psychology, and philosophy, namely the importance of conscious experience of one's own mental images in everyday functioning. Based on the literature review and the case study, we can speculate that the lack of mental images may be experienced as something that one can be curious about (Watkins, 2018) and as a severe impairment (de Vito and Bartolomeo, 2016). Possibly, the impact of aphantasia may depend on whether this condition is acquired or congenital and whether individuals suffer from particular psychopathologies, such as anxiety and depressive disorders. Furthermore, even though visual imagery does not seem to be necessary for self-awareness (Watkins, 2018), aphantasia may affect the quality of experiences in terms of the amount of visual details or access to emotional aspects of past memories (e.g. Greenberg and Knowlton, 2014; Vannucci et al., 2016).

Finally, A.B. showed good performance in verbal tasks and a preference for verbal cognitive style. It suggests that the alternative strategies that aphantasic individuals employ rely not only, as suggested above, on spatial processing, but also on verbal coding. It may be a strategy where spatial imagery is mixed with verbal rather than visual coding of spatial locations. Here, aphantasia provides a reminder that individual differences should be always taken into consideration when examining mental imagery.

Clearly, all these conclusions and hypotheses call for further empirical scrutiny and this brief summary has already proven how inspiring aphantasia can be. Future research would greatly benefit from experimental protocols and 
neuroimaging techniques for in-depth studies on dissociation between memory and imagery, and possibly, on the different strategies that people with aphantasia use. These compensatory strategies may be difficult to assess through introspection, therefore, neuroimaging may be very useful in gaining insight into the nature of these strategies. Moreover, aphantasia can provide an insight into the role of imagery in perception, memory, attention and other cognitive processes. Also, it could shed light on the relationship between imagery and social functioning as well as emotional processing of past, present and future experiences. Finally, work with aphantasic individuals can help build therapeutic and educational programs adequate for people with less vivid imagery. The results could not only expand our understanding of memory and imagery, but also help people with aphantasia to understand its influence on their everyday lives.

Last but not least, aphantasia has a series of implications for clinical practice. As can be noted from the theoretical introduction and the case study, aphantasia seems to be linked to less vivid, and more emotionally neutral, autobiographical memories. This phenomenon may stem from different sources that call for experimental investigation. It is possible, for example, that aphantasia limits access to emotional information, making it difficult to establish the personal significance of various events. On the other hand, however, it may be that the individuals with aphantasia have access to emotional information, but their emotional reaction to them is attenuated. Finally, it is possible that the information is already stored without emotional connotations or that aphantasia can block access to some memories completely if these memories are coded as images. For example, the earliest autobiographical memories are coded as single scene-images (Cowan and Davidson, 1984). As a consequence, an aphantasic individual can have difficulties in retrieving these events and referring to them as a matrix of cognitive and emotional patterns used in adulthood during social relationships, including therapeutic relation. In turn, in the course of psychotherapy, modifications of these patterns may be more difficult. Finally, many various psychotherapeutic approaches involve the use of imagery. In the case of aphantasia, a therapist needs to consider this particular phenomenon and adjust the strategy of intervention. To conclude, the aim of this paper was to introduce the concept of aphantasia and show its significance for research in psychology and clinical practice. We reviewed literature on aphantasia and memory, and analysed a case study of an aphantasic individual with special regard to how the lack of imagery affects memory and general cognitive functioning. It seems that mental imagery may be not necessary to perform memory tasks and to score high in intelligence tests. Instead, it may be viewed as an additional memory-boost strategy. Moreover, we propose that treating aphantasia as a lack of imagery may be too limited and inaccurate as aphantasia may affect only one particular type of imagery i.e., object-imagery. Therefore, the phenomenon of aphantasia is an important argument for complex theories of mental imagery and the need to consider individual differences. Finally, we believe that aphantasia presents a challenge for imagery-based psychotherapy techniques and may impact the course and effectiveness of psychotherapy. Taken together, we hope it can inspire much-needed empirical research before we can understand how exactly mental imagery affects cognitive and emotional processing as well as psychotherapy.

\section{Conflict of interest}

The authors declare no conflicting interests that could affect the content of this publication.

\section{Acknowledgments}

We thank Magdalena Szubielska for making available the Polish version of OSIVQ.

\section{References}

Baddeley A: Working memory. Science 1992; 255: 556-559.

Baddeley AD, Andrade J: Working memory and the vividness of imagery. J Exp Psychol Gen 2000; 129: 126-145.

Blajenkova O, Kozhevnikov M, Motes MA: Object-spatial imagery: a new self-report imagery questionnaire. Appl Cogn Psychol 2006; 20: 239-263.

Blazhenkova O, Kozhevnikov M: The new object-spatial-verbal cognitive style model: theory and measurement. Appl Cogn Psychol 2009; 23: 638-663.

Bruyer R, Scailquin JC: The visuospatial sketchpad for mental images: Testing the multicomponent model of working memory. Acta Psychol (Amst) 1998; 98: 17-36.

Brzeziński J, Gaul M, Hornowska E et al.: Skala Inteligencji D. Wechslera dla Dorosłych. Pracownia Testów Psychologicznych Polskiego Towarzystwa Psychologicznego, Warszawa 2007.

Cowan N, Davidson G: Salient childhood memories. J Genet Psychol 1984; 145: 101-107.

Greenberg DL, Knowlton BJ: The role of visual imagery in autobiographical memory. Mem Cogn 2014; 42: 922-934.

Gur RC, Hilgard ER: Visual imagery and the discrimination of differences between altered pictures simultaneously and successively presented. Br J Psychol 1975; 66: 341-345.

Heuer F, Fischman D, Reisberg D: Why does vivid imagery hurt colour memory? Can J Psychol 1986; 40: 161-175.

Jacobs C, Schwarzkopf DS, Silvanto J: Visual working memory performance in aphantasia. Cortex 2018; 105: 61-73.

Keogh R, Pearson J: Mental imagery and visual working memory. PLoS One 2011; 6: e29221.

Keogh R, Pearson J: The blind mind: no sensory visual imagery in aphantasia. Cortex 2018; 105: 53-60.

Keogh R, Pearson J: The sensory strength of voluntary visual imagery predicts visual working memory capacity. J Vis 2014; 14 : 7.

Kessels RP, van Zandvoort MJ, Postma A et al.: The Corsi Block-Tapping Task: standardization and normative data. Appl Neuropsychol 2000; 7: 252-258.

Kopelman MD, Wilson BA, Baddeley AD: The autobiographical memory interview: a new assessment of autobiographical and personal semantic memory in amnesic patients. J Clin Exp Neuropsychol 1989; 11: 724-744.

Kosslyn SM, Ganis G, Thompson WL: Neural foundations of imagery. Nat Rev Neurosci 2001; 2: 635-642.

Kozhevnikov M, Hegarty M, Mayer RE: Revising the visualizer-verbalizer dimension: evidence for two types of visualizers. Cogn Instr 2002; 20: 47-77. 
Kozhevnikov M, Kosslyn S, Shephard J: Spatial versus object visualizers: a new characterization of visual cognitive style. Mem Cognit 2005; 33: 710-726.

Kozhevnikov M, Kozhevnikov M, Yu CJ et al.: Creativity, visualization abilities, and visual cognitive style. Br J Educ Psychol 2013; 83: 196-209.

Marks DF: Visual imagery differences in the recall of pictures. Br J Psychol 1973; 64: 17-24.

Paivio A: Dual coding theory: retrospect and current status. Can J Psychol 1991; 45: 255-287.

Palombo DJ, Alain C, Soderlund $\mathrm{H}$ et al.: Severely deficient autobiographical memory (SDAM) in healthy adults: a new mnemonic syndrome. Neuropsychologia 2015; 72: 105-118.

Reisberg D, Leak S: Visual imagery and memory for appearance: does Clark Gable or George C. Scott have bushier eyebrows? Can J Psychol 1987; 41: 521-526.

Reisberg D, Pearson DG, Kosslyn SM: Intuitions and introspections about imagery: the role of imagery experience in shaping an investigator's theoretical views. Appl Cogn Psychol 2003; 17: 147-160.

Ross B: Aphantasia: how it feels to be blind in your mind. 2016. Available from: https://www.facebook.com/notes/blake-ross/aphantasia-how-it-feels-to-be-blind-in-your-mind/10156834777480504/ [cited: 22 October 2017].

dos Santos RG, Enyart S, Bouso JC et al.: "Ayahuasca turned on my mind's eye": enhanced visual imagery after ayahuasca intake in a man with "blind imagination" (aphantasia). J Psychedelic Stud 2018; 2 : 74-77.
Simeon D, Guralnik O, Hazlett EA et al.: Feeling unreal: a PET study of depersonalization disorder. Am J Psychiatry 2000; 157: $1782-1788$

Vandenberg SG, Kuse AR: Mental rotations, a group test of threedimensional spatial visualization. Percept Mot Skills 1978; 47: 599-604.

Vannucci M, Mazzoni G: Individual differences in object and spatial imagery: personality correlates. Pers Individ Dif 2009; 46: 402-405.

Vannucci M, Pelagatti C, Chiorri C et al.: Visual object imagery and autobiographical memory: object imagers are better at remembering their personal past. Memory 2016; 24: 455-470.

de Vito S, Bartolomeo P: Refusing to imagine? On the possibility of psychogenic aphantasia. A commentary on Zeman et al. (2015). Cortex 2016; 74: 334-335.

Walker L: Case JP: Twenty experiments on a person with Congenital Prosopagnosia and inability to experience visual imagery from birth. The Plymouth Student Scientist 2010; 3: 113-141.

Watkins NW: (A)phantasia and severely deficient autobiographical memory: scientific and personal perspectives. Cortex 2018; 105: 41-52.

Zeman A, Dewar M, Della Sala S: Lives without imagery - congenital aphantasia. Cortex 2015; 73: 378-380.

Zeman AZJ, Della Sala S, Torrens LA et al.: Loss of imagery phenomenology with intact visuo-spatial task performance: a case of 'blind imagination.' Neuropsychologia 2010; 48: 145-155. 